\title{
Curiouser and Curiouser: The Practice of Nonfiction Today
}

Keynote address, NonfictioNow conference, November 10, 2005

When I was first invited to speak at this conference on nonfiction, I imagined myself safely sandwiched between such luminaries as Pico Iyer, Lauren Slater, Bob Shacochis, David Shields and other distinguished participants. Then I discovered that I was slated to give the keynote address-a horrifying prospect. The term "keynote speaker" connotes someone who will make large generalizations that sum up the field and boost the morale of the troops. Political conventions usually turn to a rising star in the party, someone with charisma and glamour, a Barack Obama, not an old skeptic like me. But I will do my best to lift your spirits. Lord knows, nonfiction may be in need of morale-boosting.

Consider the very name of this thing we practice, a genre defined by what it is not. Like the Uncola, the Anti-Christ, or anti-matter. In the last twenty years some attempt has been made to cloak ourselves with dignity by adding the word "creative" before nonfiction; but this is tantamount to saying "good poetry." No one sets out to write "uncreative nonfiction." I myself prefer the more traditionalsounding term "literary nonfiction," though I have to admit that "literary" is also a bit of gratuitous self-praise. Our boastful insecurity mirrors, in a way, the larger literary world's condescending attitude toward our area of endeavor. Every year the cash prizes for the Whiting and Rona Jaffe fellowships, the Lannans and the MacArthurs, are announced: a healthy list of fiction writers and poets, and one or two nonfiction writers, if that. When was the last time a Nobel Prize was given to a nonfiction writer? Personal essay collections, even by such established masters as Edward Hoagland, Nancy Mairs and Joseph Epstein, are relegated to The New York Times "Books In Brief" column, as though the whole genre were a dodge to get around writing a real book.

Those of us who teach or study creative writing in university settings know that, in the beginning, God created Fiction and Poetry, and saw that it was good; and then some whiners started demand- 
ing nonfiction courses. In my visits to campuses across the country, I have been approached by graduates who stole up to me like members of an early Christian sect and told me of their struggles to receive the first MFAs for a creative nonfiction thesis; and even these were often begrudgingly awarded, as though not meant to be a genuine passport, only a visa. We nonfiction writers are the resident aliens of academia.

Yet the curious thing is that enrollments in nonfiction have held steady, even risen in places over the years. At first this student interest was attributed to the memoir "craze" (note how easily any interest in autobiographical prose, one of the oldest and most difficult literary practices extant, can be denigrated as a narcissistic fad); but when the hoopla about the "new memoir" had settled down, after a marketplace "correction," creative writing majors and graduate students continued to seek out nonfiction courses. I think the main reason is that many students experience their own reality with more confidence than an imagined one. They think they have no imagination and so they are better suited to nonfiction. Eventually they will be disabused of this misconception, when they discover that it takes just as much imagination to construct a meaningful order and context for these lived experiences, and an intriguing personality through which to tell them, as to make up a new set. But in the meantime, the misunderstanding that nonfiction is easier can be fruitful in attracting candidates to an otherwise daunting task.

Today, no sooner does the would-be nonfiction writer begin to practice than a sort of "fiction envy" must be confronted. This envy is not surprising, when you consider the higher status that fiction holds in the literary pantheon. But even if a student is content with the lower-status virtues of nonfiction, she will undoubtedly encounter creative writing instructors along the way who tell her to "put everything in scenes," for instance, or to use lots of images and sense-details, or to stay away from generalizations and abstractions. Here, the more elaborated techniques of the short story workshop have an advantage over the still-evolving pedagogy of nonfiction: they can simply be plugged into the text by following clear, simple rules. When in doubt, make it a scene. Many nonfiction instructors today received their MFAs in fiction, and were instilled with these rules. One of the leaders of our field, Lee Gutkind, has even declared that the goal of creative nonfiction is "you are trying to write the 
truth and making it read like a short story or fiction." In an interview with Donna Seaman, he provided this definition: "Creative nonfiction allows the nonfiction writer to use literary techniques usually used only by fiction writers, such as scene-setting, description, dialogue, action, suspense, plot. All those things that make terrific short stories and novels allow the nonfiction writer to tell true stories in the most cinematic and dramatic way possible. That's creative nonfiction."

I don't wish to start a polemical feud for provocation's sake, since in some ways I'm in agreement with Gutkind: if he means that a piece of nonfiction should have a plot, suspense and strong characterization-even character development in the case of the memoir-I'm all for that. And if he means that the nonfiction writer should be conscious of constructing an artifact, an artfully shaped entity, with a subjective as well as an objective component, all the better. But if he means that you should try as much as possible to render everything in scenes, and to make sure you've sprinkled sense-details everywhere and try to make it as "cinematic" as possible, and that you've stayed away from thoughtful analysis because it's "abstract," then, no, I don't agree.

For all their shared boundaries, it seems to me, the experiences of fiction and nonfiction are fundamentally different. In the short story or novel, a fictive space is opened up in which the reader tends to disappear into the action, even to the point of forgetting one is reading. In the best nonfiction, it seems to me, you're always made aware that you are reflecting, by being engaged with a mind at work, not falling into a dream. There is a strong plot, certainly, but the plot in nonfiction consists of the twists and turns of a thought process as it works itself out. This is certainly true for the essay, but it is also true, I think, to much nonfiction in general, which follows an organizing principle that can be summarized as: tracking the consciousness of the author.

What makes me want to keep reading a nonfiction text is the encounter with a surprising, well-stocked mind as it takes on the challenge of the next sentence, paragraph, thematic problem it sets itself. The other element that keeps me reading happily is an evolved, entertaining, elegant or at least highly intentional literary style. The pressure of style is brought to bear on every passage. Consciousness plus style equals good nonfiction, in my book. 
For me, as I say, the great adventure in reading nonfiction is to follow a really interesting, unpredictable mind as it struggles to entangle and disentangle itself in a thorny problem, or even a frivolous problem that an interesting mind finds a way to make complex. George Orwell reflecting on his ambivalence toward Gandhi, Robert Benchley meditating on his face, Seymour Krim on failure, Susan Sontag on photography, Stendhal on love, Montaigne on experience, Norman Mailer on sex, Virginia Woolf on a room of one's own or the death of a moth, Loren Eiseley on the brown wasps, Edmund Wilson on the development of socialist thought, Charles Lamb on married couples, Joan Didion on migraines, William Gass on the color blue.... None of these read like short stories or like screenplays, but like what they are: glorious thought-excursions. I have purposely mixed longer, book-length tracts in with smaller essays, to make the point that the pursuit of consciousness is not just the prerogative of the short-sprint personal essayist. Indeed, there is something about consciousness which is almost infinitely extensible-frighteningly so. One thought leads to another, and another, and pretty soon you have Robert Burton's thousand-page Anatomy of Melancholy.

George Steiner wrote an essay recently which he entitled "Ten (Possible) Reasons for the Sadness of Thought." The first he gave was that "thought is infinite," though because it is subject to doubt, or (to use Steiner's words) "internal contradiction for which there can be no resolution," it is an "incomplete infinity." His second reason was that thought is uncontrolled, involuntary, and disorganized. The third is that thought isolates us: no one can read our minds, or think our thoughts for us. (Notice, by the way, that each of the reasons Steiner offers for why thought makes us sad could just as easily be seen as a cause for celebration.) At the same time, he says, as thought cuts the individual off from others, almost everything an individual thinks is banal, unoriginal, hence, the worst of both worlds. Steiner's fourth reason is that there is an inherent collision between rational demands for thought to have one truthful, verifiable meaning and the tendency of language to suggest ambiguous, evasive, multiple meanings. The fifth reason is that thought is incredibly wasteful; even Einstein claimed he had only two ideas in his entire life and the rest was dross. The sixth reason for thought to make us sad is that it causes us to have fantasies and unrealistic 
expectations which are then frustrated and disappointed by reality. Wait-I'm more than halfway through. Seventh reason: we cannot arrest thought, it keeps going incessantly, like our heartbeat, and it veils as much as it reveals. Eighth reason: thinking keeps us strangers from one another, prevents true empathy. (I believe Steiner is starting to repeat himself at this point.) Ninth reason: the enormous disparity between clever people and dull-witted ones, and the near-impossibility of teaching skills of original thinking, leads to elitism and profound social injustice. And the tenth reason (I sound like David Letterman): the capacity for thought shows its limits as soon as one tries to brood over the most important questions-being, death, God—and leads us into a glib agnosticism or a dangerous religious fundamentalism.

Have I cheered you up sufficiently? Have I raised group morale yet? My point in all this is to suggest that the larger culture, and our specific subculture of nonfiction, may be moving away from consciousness for understandable, if not laudable, reasons. If thinking on the page makes us sad, why do it? If all those semi-colons, ideas and oppositional clauses slow us down, and keep us from the more tactile pleasure of sense details and speedy dialogue and cinematically imaginable scenes, hey, get rid of them!

I can think of another reason, which Steiner doesn't mention, why thoughts make us sad, or rather, guilty, but why we so need to keep expressing them. We may feel we know too much, or come to know it too early. It's the burden of precocity. During the years I taught children writing, I saw that a typical eleven-year-old, say, has inside himself or herself both a four-year-old who is still very babyish and imperious, and a tired forty-year-old who knows the score. Children play to the expectations adults have of them to behave in a child-like manner, but inside, they don't regard themselves as innocent, so much as confused. I grew up with the guilty sense that a part of me was faking being a child; I was already an old soul. Lots of people are like that, particularly people who become writers, but nobody told me I was not unusual then, so I had to figure it out on my own.

Consciousness makes us aware that we are divided, are made of many disparate, contradictory parts. When children, caught in the act of doing something wrong, insist "It wasn't my fault," what do they mean exactly? One part of them knows very well it was 
their fault, and another part of them believes it isn't, because it's the fault of a world so poorly constructed as to have tempted them into a wrongful act. A part of them wants to believe that they are indeed innocent angels, as adults tell them they are, just as the adults tell them Santa Claus is real. But they themselves are already conscious. And guilt and shame come from consciousness, not from doing evil. Dostoevsky's narrator in Notes From Underground asserts that "consciousness is a disease." Of course the Underground Man is boasting and proud of his consciousness, a disease he wouldn't mind infecting everyone with.

If consciousness isolates, it also heals, consoles. My own writing is saying, or trying to, in effect: "This is my consciousness, now go off and don't feel so guilty about your consciousness. If you are having wicked, perverse, curmudgeonly, antisocial thoughts, know that others are having them also." Just being conscious, aware of the peculiarities of others and self-aware of one's idiosyncratic thought patterns from moment to moment, engenders guilt. I've come to understand that more and more, by working with and teaching the personal essay.

Let me speak of another guilt here. A graduate student who had studied with me and then had gone on to take a workshop with another professor, told me she was embarrassed and perplexed about something, and could I help her out. I said sure, I could try. She said that in her first workshop session the professor had admonished them that they had to write from their passions, follow their obsessions. I knew where the professor was coming from; I've given plenty of such pep talks myself using go-get-'em formulae, especially when I had to fill out the first hour before sending them home with the syllabus; but I also sympathized with the student, a smart, talented woman and an excellent personal essayist, when she confessed that she didn't think she had any obsessions. She felt guilty about not being obsessed, and feared it indicated she might be shallow.

I told her I thought that obsession was a much overrated concept. First of all, it was rarer in real life than in novels or movies. When an independent filmmaker without much of an idea starts shooting a film, he gets a pretty woman to walk around the moody rain-slicked streets, and then-because he knows he's got to have a plot-he gets his hero or anti-hero to follow her. In arty films, 
obsession is the last refuge of plot desperation to pull together random footage. In real life, it's not so easy to be obsessed. You say to yourself, I think I'll stalk that person who's been on my mind, and then you say, Nah, I have to finish my work, or, No, that's silly, she's not going to like me any better because I'm following her around. The practical mind kicks in. There have been times in my life when I actually tried to promote an obsession with someone or something, just because it would seem like a solution to feeling at loose ends, and in the middle of obsessing, or trying to, I would start to giggle, as much as to say: Who am I kidding?

Maybe I'm just not the obsessive type, and generalizing too much from narrow experience; but I continue to believe that obsession is more of a romantic construct than an everyday occurrence. The second problem with obsession is that it tends to go nowhere. I have met obsessive types on the road through life, and for the most part they were pretty boring. Obsessives tend to repeat themselves, while ignoring other people or other stories breaking around them; it's a very narcissistic pattern of intellection, so I'm not sure how useful it is in the production of essays and other nonfiction. I'm tempted to say obsession is a fiction concept, we don't need it.

Okay, fine, we don't have to start from obsession; then what do we need to generate nonfiction? I would say, curiosity. It sounds more tepid than obsession, but it's a lot more dependable in the long run. You follow out a strand of curiosity and pretty soon you've got an interesting digression, a whole chapter, a book proposal, a book. The solution to entrapment in the hothouse of self is not to relinquish autobiographical writing, as though we had to buy into the anti-memoir backlash that says memoirs are self-absorbed navel gazing. That's bullshit. No, the solution is to expand the self by getting it to interface in curiosity with more and more parts of history and the concrete world. In practical terms, this is the second-book problem for the successful memoirist. If the first book you wrote was very successful, I suppose you can keep publishing one memoir after another, like 'Tis after Angela's Ashes or Cherry after The Liars' Club; but eventually, you're going to have to mine new material.

In any event, this was the solution I came to after having written three collections of personal essays, two volumes of personal poetry and an autobiographical novel. I could keep cannibalizing what hunks of my body and past were still unwritten, or I could 
go out into the world and meditate, that is to say, project my consciousness onto it. So I wrote a book about the New York waterfront. I read everything I could about the history, marine biology, urban planning, literature and politics pertinent to the waterfront. I wrote about dock construction and shipworms and corrupt unions and Robert Moses and Joseph Mitchell and pirates and sailors and homeless people and public housing, and I also wrote about my own odd experiences walking the waterfront, because I found that it wasn't necessary to jettison my I-character on this journey. If anything, the voice I had developed in my personal essays was essential for welding together the clumsy, disparate materials to which my curiosity had led me. The path of my consciousness through all this obdurate matter became the unifying element.

I have a confession to make: I was never obsessed with the waterfront. It offered a pretext, a structure for me to follow out my curiosity in a few dozen different directions. I don't pretend to have hit on anything original by using this method. The formula of curiosity-driven research plus personal voice is one of the most prevalent modes we see in today's nonfiction, from Rebecca Solnit to Philip Gourevitch to Jonathan Raban to many of the people at this conference, from travel writing to nature writing to family chronicles to works of political engagement that descend from Orwell's The Road to Wigan Pier.

Not obsession but curiosity. I have the underlying conviction that nonfiction tends toward reason, calm, intelligence, insight, order. This is not necessarily a bad thing, but we sometimes feel guilty about it, we nonfiction writers, and want to heat up the form, make it more irrational. Much modernist fiction, from Dostoevsky to Faulkner, has staked out the territory of the irrational, the deranged, retarded or otherwise reason-impaired narrator. But nonfiction since at least Rousseau has traditionally encouraged readers to regard the narrator, whatever else his flaws, as reliable, and making a sincere attempt to level with us. It's the difference between Lolita and Speak, Memory - between a moral monster (as Nabokov and his wife Vera insisted the charming Humbert Humbert was) vs. a dependably reminiscent narrator.

I am intrigued in this regard by two memoirs I have read recently: Memoirs of My Nervous Illness by Daniel Paul Schreber, a nineteenthcentury jurist who suffered from paranoid delusions and was locked 
up in an insane asylum, and The Future Lasts Forever, by the French Marxist philosopher Louis Althusser, who strangled his wife in a moment of delirium. What moves me about these memoirs is that both authors were trying to write as rationally as possible about their brushes with madness. They were not writing at all for literary glory nor to flirt with a poetic "derangement of the senses," in the Baudelaire-Rimbaud manner, but were compelled, as it were, to keep their sanity, or whatever shards still existed, by trying to relate the horrible experience of losing their minds. We tend to forget that Reason can be a rare, prized, hard-to-regain commodity. So let us not disdain the classic mandate of the nonfiction writer to make sense of the world, to tell about it in lucid, rational terms.

We always come back to that strange prohibition, "Show, don't tell." It reminds me of the Clinton administration's order on gays in the military: "Don't ask, don't tell." Why this repression of the telling voice today? Traditionally, you called someone who could deliver a narrative from a particularly sharp, juicy point of view, a "story-teller." Nothing is more natural than for a writer to tell-to use summary, context and analysis when putting across a particular subject, particularly in nonfiction. I understand, I think, some of the legitimate mistrust of telling which my students voice in a creative writing workshop, even one in nonfiction: they object to some kind of assertion or run of assertions that isn't backed up with specifics. They don't want the writer to do the work for them. They would prefer to come to their own conclusions based on indirect hints and suggestions. Myself, I don't see anything wrong with the writer sharing conclusions directly with the reader; where does it say that Jamesian indirection is the one and only valid literary method? But if you're going to tell us directly what's in your mind, I do think you as the writer have an obligation to make the "telling" passages particularly vivid, so that the drama of a voice telling us all it can, with complete candor, can allay the contemporary reader's fears of pallid summarizing. Let us agree to show and tell.

There remains the fear of endless yammering. (I assure you, I'll be through in a few minutes.) How does consciousness, once it gets going, know when to stop? "I think therefore I am" becomes "As long as I'm thinking, I'm still alive"-a way to cheat death, especially for the person who finds himself prematurely buried. Poe understood that Gothic dimension of consciousness. There are 
certain authors associated in a good sense with endless consciousness, such as Montaigne, Whitman, Proust, whose urge to keep cataloguing and qualifying their single ever-expanding text could never cease until death put a stop to it.

One of my students' most frequent questions, and I am never sure how to answer it, is: How do you know when to end an essay? Perhaps the answer is: When your hand gets tired. We know that an essay must conclude as a technical matter, because the reader cannot take any more-not necessarily because a conclusion has been reached in the author's mind, or staged as inevitable. In fact, inevitability is to be avoided in essays for as long as possible. The form must be kept open, the lines of inquiry left receptive to new curiosities.

Sometimes the word "truth" is also brought up in relation to nonfiction. I suppose nonfiction has some relationship to the pursuit of truth-it is one of the last remaining dignities that can reasonably be deduced from its negative name-but as soon as I begin to write the word "truth" my palms get sweaty and I think I'm about to bluff or perjure myself. "What is truth?" said Pontius Pilate, who probably wrote wonderful essays in his spare time.

I would be more willing to talk about another word, "honesty." We may not ever be in possession of the truth, but at least as nonfiction writers we can try to be as honest as our courage permits. Honest to the world of facts outside ourselves, honest in reporting what we actually felt and did, and finally, honest about our own confusions. I realize that a completely made-up fiction can achieve its own artistic "honesty," but that is a separate issue and a rather speculative use of the word. The challenge faced by the nonfiction writer is to take something that actually happened, to oneself or to others, and try to render it as honestly and compellingly as possible. I realize that in giving it shape, the nonfiction writer may be obliged to leave out many facts, combine incidents or rearrange chronologies. Fine: I am not a stickler about these matters, and do not think we need apply the strictest journalistic standards of factual accuracy to all literary nonfiction. The press spends far too much time worrying these bogus ethical questions, such as was Vivian Gornick right to use "composite figures" in a memoir, probably because it is easier to generate an air of scandal and controversy by pouncing 
on discrepancies between the written and lived record than it is to fathom the art of the memoir.

My own feeling is that, all things considered, and whenever possible (it's not always possible), I would rather employ the actual facts in a nonfiction piece, because there is something magical and uncanny about the world that is given to us, in the very randomness or order that it is given to us. As soon as we change a person's profession from, say, writer to architect, or a place-name from Indianapolis to San Jose, or the age that one lost one's virginity from twenty-one to nineteen, some tension goes out of the piece. It's the tension of trying to render precisely the thing that happened, the way Albrecht Dürer would try to draw a model by looking through a gridded scrim and transferring the thing in front of him, square by square, onto his paper with charcoal. No doubt there are equally significant tensions that the fiction writer follows. I've written two novels and a bunch of other fiction myself, so I know. But perhaps because I do keep writing fiction (at the moment I'm working on a novella), I see no reason to try to make my nonfiction read like fiction. I can appreciate that the attributes of nonfiction possess their own charm and validity, and I'm not so drawn to hybridizing the forms. But many are.

The other day I was rushing to a doctor's appointment and I passed someone who had the New York Post open to a big tabloid headline, "Nonfiction Reads Like Novel," with a picture of gossip columnist Liz Smith grinning beneath it. Holy moly, I thought, everyone's getting into the act! I mean, I started to feel persecuted, there were signs everywhere. It turns out $\mathrm{Liz}$ was plugging her friend John Berendt's new book, The City of Falling People, and I quote: "This tale of the glamorous, fetid, mythic, schizophrenic, slowly sinking city on the Adriatic Sea-along with its evasive denizens-makes for a hypnotic read. Berendt is the best at what he does, and what he does is persuade the reader to close his book and say, 'What a fabulous novel!' Then you realize with a start, it's all true-facts fashioned like exquisite Venetian glass." Now, I would have thought that facts fashioned like exquisite Venetian glass would be considered at least as much the province of nonfiction as fiction. Look at Edward Gibbon's magisterial synthesizing of historic details in The Decline and Fall of the Roman Empire, which no one ever accused of sounding like a novel, though it is a wonderful 
story. The key genre-merging distinction in Liz Smith's excitable description is not about facts being like glass, it seems to me, but this one: "makes for a hypnotic read." It is only when you the reader are put under a hypnotic spell that you can be said to enter fictive space. That will-less absorption in another's word-pictures, that abandonment of your mind to another's command, seems to me the siren-song of fiction. Obviously, not all fiction functions this way, or demands such surrender, but the "hypnotic" state, I believe, represents the ideal condition when people speak about nonfiction reading like fiction. In the same manner, many fledgling memoirists today lock themselves into a hypnotic present tense, because it allows them the fantasy that they are re-experiencing the past as a sort of numbed victim moving through a dream, rather than interrogating their own complicity in the proceedings with the benefit of hindsight and the perspective of hard-won wisdom.

I confess that I am more and more drawn to reading autobiographical nonfiction, because the older I get the more difficult it is to accept the contrivance of fiction. I have a friend who is a novelist and who keeps writing personal essays on the side, not seriously, more like a holiday from fiction. Often, when I read her novels, which are always ambitious, I get the feeling that the characters and situations are contrived, and the plot mechanically forced towards tragedy or farce. Then I pick up a personal essay by her and it's a gem: completely convincing, witty, relaxed, with a warmly intelligent narrative voice. The reason is probably that she didn't have to invent, she could just sculpt into words a piece of lived experience-not an easy thing to do, but since she is already a trained literary artist, she knows how to go about doing it. Sometimes imagination can be too facile, too cheap, and would benefit from a disciplined restraint put on it.

Last year, I heard the great Philip Roth deliver a talk on his latest novel, The Plot Against America. What struck me most was his saying that every night he would go to bed and tell himself: "Don't invent, remember!" Sure enough, the first two-thirds of that novel are remarkable because of how everyday and plausible the events seem, how close to remembered fact; it's only in the last third, when the plot gets busy and wacky, that the book loses its magnificence and becomes overly mechanical. We nonfiction writers shouldn't be so in awe of invention; it's a fairly cheap knack. We also need to 
recognize that some of the best writers of the past fifty years, such as Mary McCarthy, George Orwell, James Baldwin, Gore Vidal, Norman Mailer, and Joan Didion, were arguably better at nonfiction than fiction. None of them ever created a character as vibrant as his or her nonfiction narrator, be it Mary, George, Jimmy, Gore, Aquarius, or Joan. So nonfiction has nothing to apologize for. It can hold its head up high.

I believe I have run out of thoughts for the moment. Thank you for listening patiently. 